\title{
PENGARUH KEPEMIMPINAN KEPALA SEKOLAH DAN BUDAYA SEKOLAH TERHADAP KINERJA GURU PADA SMP NEGERI 1 PANEI
}

\author{
Oleh: \\ Rame Uli Orisa Sidabutar \\ S1 Manajemen \\ Darwin Lie, Efendi, Ady Inrawan
}

Abstraksi

Adapun rumusan masalah penelitian ini adalah bagaimana pengaruh kepemimpinan kepala sekolah dan budaya sekolah terhadap kinerja guru pada pada SMP Negeri 1 Panei. Metode yang digunakan dalam penulisan ini adalah penelitian kepustakaan dan penelitian lapangan. Populasinya adalah seluruh guru berjumlah 48 orang. Data yang digunakan adalah data kualitatif dan data kuantitatif, dan teknik pengumpulan data yang digunakan adalah metode kuesioner, metode wawancara dan metode dokumentasi. Kemudian teknik analisis data menggunakan metode deskriptif kualitatif dan metode deskriptif kuantitatif.

Hasil penelitian: 1. Kepemimpinan kepala sekolah sudah baik, dan budaya sekolah kuat serta kinerja guru juga sudah baik. 2. Hasil analisis regresi adalah $\hat{Y}=21,276+0,839 X_{1}+1,089 X_{2}$, artinya kepemimpinan kepala sekolah dan budaya sekolah berpengaruh positif terhadap kinerja guru. 3 . Hasil analisis koefisien korelasi diperoleh nilai $r=0,712$, artinya terdapat hubungan yang kuat dan positif antara kepemimpinan kepala sekolah, budaya sekolah dengan kinerja guru pada SMP Negeri 1 Panei. Baik tidaknya kinerja guru sebesar $50,7 \%$ dapat dijelaskan oleh kepemimpinan kepala sekolah dan budaya sekolah. 4. Hasil uji hipotesis menyatakan $\mathrm{H}_{0}$ ditolak, kepemimpinan kepala sekolah dan budaya sekolah berpengaruh positif dan signifikan terhadap kinerja guru pada SMP Negeri 1 Panei baik secara simultan maupun parsial.

Kata kunci: Kepemimpinan Kepala Sekolah, Budaya Sekolah dan Kinerja Guru

\section{Abstraction}

The formulation of this research problem is how the influence of principal leadership and scholl culture on teracher perfomance at SMP Negeri 1 Panei. The method used in this paper is literature research and field research. The population is all teachers of SMP Negeri 1 Panei which amounted to 48 people. The data used are qualitative data and quantitative data, and data collection techniques used are questionnaire method, interview method and documentation method. Then the technique of data analysis using qualitative descriptive method and quantitative descriptive method.

The result of this study can be summarized as follows: 1. Leadership of the principal is good, the culture of school is strong and the teacher performance is also good. 2. The results of regression analysis is $\hat{Y}=21,276+0,839 \mathrm{X}_{1}+1,089 \mathrm{X}_{2}$, its means that principal leadership and school culture had a positive effect on teacher performance. 3 . The results of the analysis correlations get value $r=0,712$, it means that there is a strong and positive relationship between principal leadership, school culture to the teacher performance at SMP Negeri 1 Panei. The level of teacher performance can be explained by principal leadership and school culture as big as 50,7\%. 4. The results of testing the hypothesis $\mathrm{H}_{0}$ is rejected, its means that principal leadership and school culture had a positive and significant effect to the teacher performance at SMP Negeri 1 Panei auction both of simultaneous or partial.

Keywords: Principal Leadership, School Culture and Teacher Performance

\section{A. PENDAHULUAN}

\section{Latar Belakang Masalah}

Pendidikan merupakan sesuatu yang tidak asing bagi kita dan tentu pendidikan diperlukan semua orang. Bahkan dapat dikatakan bahwa pendidikan dialami oleh semua manusia dari semua golongan. Dalam UU No. 20 tahun 2003, pendidikan merupakan usaha sadar terencana untuk mewujudkan suasana belajar dan proses pembelajaran agar peserta didik secara aktif mengembangkan potensi dirinya. Keberhasilan pencapaian tujuan pendidikan terutama ditentukan oleh proses pembelajaran yang dialami siswa. Dengan proses pembelajaran diharapkan adanya peningkatan aspek pengetahuan, sikap dan keterampilan siswa.

Sekolah Menengah Pertama (SMP) 1 Panei merupakan salah satu jenjang pendidikan yang dikelola oleh pemerintah. Sekolah Menengah Pertama (SMP) Negeri 1 Panei berlokasi di Jalan Siantar-Seribudolok KM.13 Kec. Panei Kab.Simalungun. Sekolah yang baik dapat dilihat dari kinerja guru yang berada 
didalamnya, untuk itu kinerja guru perlu diperhatikan dengan baik karena dengan kinerja guru yang baik akan menentukan berhasil tidaknya sekolah mencapai tujuannya.

Dimensi kepemimpinan kepala sekolah adalah kepribadian, manajerial, kewirausahaan, supervisi dan sosial. Fenomena kepemimpinan kepala sekolah SMP Negeri 1 Panei terjadi pada dimensi kepribadian dengan indikator keinginan kepala sekolah untuk pengembangan diri, hal ini dapat dilihat kepala sekolah yang kurang memiliki keberanian untuk mengembangkan potensi yang ada dalam diri kepala sekolah. Sedangkan pada dimensi manajerial, kewirausahaan, supervisi dan sosial, kepala sekolah pada SMP Negeri 1 Panei memiliki perilaku yang baik dimana kepala sekolah memiliki kemampuan untuk memberdayakan sumber daya sekolah, mampu memotivasi warga sekolah untuk mencapai keberhasilan sekolah, dan mampu berpartisipasi dalam kegiatan sosial kemasyarakatan.

Selain kepemimpinan kepala sekolah, budaya sekolah juga sangat berperan penting karena dengan budaya sekolah diharapkan memperbaiki mutu sekolah, kinerja di sekolah dan mutu kehidupan yang ada pada sekolah tersebut. Budaya pada SMP Negeri 1 dapat kita lihat pada sekolah tersebut seperti bentuk bangunan sekolah, ornamen-ornamen yang berhubungan dengan unsur batak, hal tersebut yang membuat sekolah didaerah simalungun ini unik dan berbeda.

Indikator budaya sekolah meliputi inisiatif individu, pengarahan, integrasi, dukungan manajemen, kontrol, identitas, sistem imbalan, dan pola komunikasi. Fenomena budaya sekolah SMP Negeri 1 Panei terjadi pada indikator pola komunikasi dengan kategori hirarki formal membatasi komunikasi yang terjadi di sekolah, hal ini ditunjukkan sikap para guru yang terkadang kurang memperhatikan dalam melakukan tugasnya yang diberikan pimpinan.

Kepemimpinan kepala sekolah yang baik serta budaya sekolah yang kuat akan meningkatkan kinerja guru.

\section{Rumusan Masalah}

a. Bagaimana gambaran kepemimpinan kepala sekolah, budaya sekolah dan kinerja guru pada SMP Negeri 1 Panei.

b. Bagaimana pengaruh kepemimpinan kepala sekolah dan budaya sekolah terhadap kinerja guru pada SMP Negeri 1 Panei secara simultan maupun parsial.

\section{Tujuan Penelitian}

a. Untuk mengetahui gambaran kepemimpinan kepala sekolah, budaya sekolah dan kinerja guru pada SMP Negeri 1 Panei. b. Untuk mengetahui pengaruh kepemimpinan kepala sekolah dan budaya sekolah terhadap kinerja guru pada SMP Negeri 1 Panei secara simultan maupun parsial.

\section{Metode Penelitian}

Objek penelitian adalah SMP Negeri 1 Panei yang terletak di Jalan Siantar-Seribudolok KM.13 Kecamatan Panei, Kabupaten Simalungun. Populasi adalah semua guru SMP Negeri 1 Panei yang berjumlah 48 orang.

Desain penelitian adalah Penelitian Kepustakaan (Library Research) dan Penelitian Lapangan (Field Research). Teknik pengumpulan data berupa Kuesioner, Wawancara dan Dokumentasi. Jenis data yang adalah jenis data kualitatif dan data kuantitatif. Hasil data yang diperoleh dari lapangan akan dianalisis secara deskriptif baik bersifat kualitatif dan kuantitatif.

\section{B. LANDASAN TEOR}

\section{Manajemen Sumber Daya Manusia}

Menurut Mondy (2008:10), manajemen sumber daya manusia adalah pemanfaatan sejumlah individu untuk mencapai tujuan-tujuan organisasi. Menurut Mathis dan John (2011:3), manajemen sumber daya manusia adalah rancangan sistem-sistem formal dalam sebuah organisasi untuk memastikan penggunaan bakat manusia secara efektif dan efisien guna mencapai tujuan-tujuan organisasi. Sedangkan menurut Rivai (2005:5), manajemen sumber daya manusia adalah pengelolaan dan pendayagunaan sumber daya yang ada pada individu (karyawan). Berdasarkan uraian teori di atas, maka dapat disimpulkan bahwa manajemen sumber daya manusia adalah bagian dari manajemen keorganisasian yang memfokuskan diri terhadap sumber daya manusia untuk mengelola manusia secara baik agar menghasilkan manusia-manusia yang berkualitas.

\section{Kepemimpinan Kepala Sekolah}

Menurut Robbins (2002:163), kepemimpinan adalah kemampuan untuk mempengaruhi suatu kelompok untuk pencapaian tujuan. Bentuk pengaruh tersebut dapat secara formal seperti tingkat manajerial pada suatu organisasi. Menurut Sutrisno (2009:213), kepemimpinan adalah suatu proses kegiatan seseorang untuk menggerakkan orang lain dengan memimpin, membimbing, memengaruhi orang lain untuk melakukan sesuatu agar dicapai hasil yang diharapkan. Sedangkan menurut Bangun (2012:339), kepemimpinan merupakan proses mempengaruhi orang lain dalam suatu organisasi agar mereka dapat melaksanakan tugasnya dengan baik dalam mencapai tujuannya. 
Menurut Wahjosumidjo (2002:83), kepala sekolah adalah seorang tenaga fungsional guru yang diberi tugas untuk memimpin suatu sekolah dimana diselenggarakan proses belajar mengajar atau tempat dimana terjadi interaks antara guru yang memberi pelajaran dan murid yang menerima pelajaran. Sedangkan menurut Rahman, dkk (2006:106), kepala sekolah adalah seorang guru yang diangkat untuk menduduki jabatan struktural di sekolah. Sementara menurut Wirawan (2014:532), kepemimpinan pendidikan (dalam hal ini kepala sekolah) merupakan proses pimpinan pendidikan mempengaruhi para peserta didik dan para pemangku kepentingan pendidikan serta menciptakan sinergi untuk mencapai tujuan pendidikan.

Menurut Peraturan Menteri Pendidikan Nasional Nomor 13 Tahun 2007 Tentang Standar Kepala Sekolah / Madrasah, Kepemimpinan kepala sekolah dapat diukur melalui kompetensi di dalam menjalankan tugas dan tanggung jawabnya, yaitu kepribadian, manajerial, kewirausahaan, supervise dan sosial.

\section{Budaya Sekolah}

Menurut Hallinger dan Leithwood dalam Susanto (2016:95), budaya sekolah merupakan penjabaran dari nilai yang diterapkan di sekolah, norma yang ada dan diberlakukan di sekolah, serta harapan dan kebiasaan yang menggambarkan interaksi timbal balik antara satu anggota dengan lainnya. Menurut Zamroni dalam Susanto (2016:94), budaya sekolah adalah pola nilai, prinsip, tradisi dan kebiasaan yang terbentuk dalam perjalanan panjang sekolah, dikembangkan sekolah dalam jangka waktu yang lama dan menjadi pegangan serta diyakini oleh seluruh warga sekolah sehingga mendorong munculnya sikap dan perilaku warga sekolah. Sedangkan menurut Renchler dalam Susanto (2016:96), budaya sekolah menekankan pada pencapaian prestasi akademik melalui pengkordinasian lingkungan lingkungan atau iklim belajar siswa karena efektifitas sebuah sekolah secara akademik tergantung pada kejelasan tujuan yang dibuat sejalan dengan prestasi yang diraih siswa, kesamaan harapan antara guru dan orang tua, dan upaya mendesain struktur yang dapat memaksimalkan kesempatan bagi siswa untuk mengikuti proses belajar mengajar.

Menurut Susanto (2016:97), budaya sekolah dapat diukur dengan beberapa indikator, yaitu: inisiatif, toleransi terhadap tindakan beresiko, pengarahan/arah, integrasi, dukungan manajemen, kontrol, identitas, system imbalan, toleransi terhadap konflik dan pola komunikasi.

\section{Kinerja Guru}

Menurut Mutohar (2013:155), kinerja guru yang efektif-konstruktif, bermula dari gaya kerja yang kreatif, inovatif penuh dedikasi dan juga bersumber dari motivasi yang berprestasi. Menurut Susanto (2016:188), kinerja guru adalah kemampuan yang ditunjukkan oleh guru dalam melaksanakan tugas atau pekerjaannya. Sedangkan menurut Supardi (2016:54), kinerja guru adalah kemampuan seorang guru dalam melaksanakan tugas pembelajaran dan bertanggung jawab atas peserta didik di bawah bimbingannya dengan meningkatkan prestasi belajar peserta didik.

Menurut Peraturan Menteri Pendidikan Nasional Nomor 16 Tahun 2007 tentang Standar Kualifikasi Akademik dan Kompetensi Guru, terdapat 14 indikator pengukuran kinerja guru yang bersumber dari kompetensi guru, yaitu menguasai karakeristik, menguasai teori belajar \& prinsip pembelajaran, pengembangan kurikulum, kegiatan pembelajaran yang mendidik, pengembangan potensi peserta didik, komunikasi dengan peserta didik, penilaian dan evaluasi, bertindak sesuai dengan norma, menunjukkan pribadi yang dewasa dan teladan, etos kerja, bersikap inklusif, komunikasi, penguasaan materi, dan mengembangkan keprofesionalan melalui tindakan yang reflektif.

\section{PEMBAHASAN}

\section{Analisa}

\section{a. Deskriptif Kualitatif}

Analisis deskriptif dimaksudkan untuk mendapatkan gambaran atau deskripsi mengenai tanggapan dari konsumen mengenai Pengaruh Kepemimpinan Kepala Sekolah dan Budaya Sekolah Terhadap Kinerja Guru Pada SMP Negeri 1 Panei. Setelah pengujian data, maka langkah selanjutnya peneliti melakukan pengkajian analisis kualitatif sebagai gambaran fenomena dari variabel penelitian pada saat sekarang ini. Adapun penetapan kriteria nilai rata-rata jawaban dari responden tersebut dimasukkan ke dalam kelas-kelas interval dimana penentuan intervalnya memakai rumus sebagai berikut:

Interval Kelas = Nilai Tertinggi - Nilai Terendah

$$
\begin{array}{ll}
-\frac{5-1}{5} & \text { Jumlah Kelas } \\
= & \frac{4}{5} \\
= & 0,8
\end{array}
$$

Dari rumus diatas dapat diperoleh interval kelas 0,8 sehingga berlaku ketentuan kategori dengan hasil berikut:

Tabel 1

\begin{tabular}{|c|c|c|c|}
\hline \multirow[b]{2}{*}{$\begin{array}{c}\text { Nilai } \\
\text { Interval }\end{array}$} & \multicolumn{3}{|c|}{ Katequri } \\
\hline & Kualilias Produk & Harga & $\begin{array}{l}\text { Kepuasan } \\
\text { Konsument }\end{array}$ \\
\hline$x=18$ & Sargat Tic z Bak & Saาç: dar.Sel.l & Sarnat Tdas ${ }^{2}$ Jas \\
\hline $21=260$ & TicasEak & Tdak Selt t & Fidas ${ }^{2} \mathrm{~J} 3 \mathrm{~s}$ \\
\hline $2,1=340$ & Qkus Jais & Kuarg Situju & C.sup Flas \\
\hline $341=420$ & Eail. & SЕ:цj & F.:35 \\
\hline $421=500$ & SargalEaik & S3าc: S:tuju & SoryatF.35 \\
\hline
\end{tabular}

Nilai Interval dan Kategori Jawaban Responden 
Sumber : hasil pengolahan data

\section{1) Gambaran Kepemimpinan \\ Sekolah pada SMP Negeri 1 Panei}

Kepemimpinan kepala sekolah adalah kemampuan untuk menggerakkan sumber yang ada pada suatu sekolah dan digunakan secara maksimal serta untuk memajukan sekolah demi tercapainya tujuan yang diharapkan Kepemimpinan kepala sekolah sangat berperan penting pada sekolah dimana dengan kepemimpinan kepala sekolah dapat memberdayakan sumber daya yang ada pada sekolah.

Pada SMP Negeri 1 Panei, kepemimpinan kepala sekolah menggunakan lima dimensi antara lain kepribadian, yaitu kepala sekolah berusaha mengembangkan dir agar lebih mampu melaksanakan tugas pokok dan fungsinya sebagai pemimpin di sekolah tersebut. Manajerial, yaitu pemimpin melakukan perencanaan untuk kegiatan sekolah untuk kemajuan sekolah. Kewirausahaan, yaitu pemimpin mampu menciptakan inovasi bagi pengembangan sekolah untuk menciptakan keberhasilan sekolah. Supervisi, yaitu pemimpin melaksanakan program-program seperti pelatihan pengajaran untuk meningkatkan keprofesionalisme guru. Dan social yang merupakan cara pemimpin menjalin kerja sama dengan pihak lain untuk pengembangan sekolah dan pemimpin ikut berpartisipasi dalam kegiatan sosial kemasyarakatan.

Secara keseluruhan kepemimpinan kepala sekolah diperoleh nilai rata-rata 3,81 dengan kriteria jawaban baik. Untuk nilai tertinggi diperoleh nilai rata-rata 4,35 dengan kriteria jawaban sangat baik pada indikator mengelola sumber daya pendukung (sarana dan prasarana). Sedangkan untuk nilai terendah yaitu diperoleh nilai rata-rata 3,15 yaitu dengan kriteria jawaban cukup baik pada indikator keinginan kepala sekolah untuk pengembangan diri.

\section{2) Gambaran Budaya Sekolah pada SMP Negeri 1 Panei}

Salah satu faktor yang dapat mempengaruhi kinerja guru dalam melaksanakan pekerjaannya adalah budaya sekolah. Budaya sekolah adalah nilai-nilai dominan yang didukung oleh sekolah yang menuntun kebijakan sekolah terhadap semua unsur dan komponen sekolah seperti cara melaksanakan pekerjaan di sekolah. Pada SMP Negeri 1 Panei, salah satu faktor penting dalam mencapai tujuan adalah budaya sekolah. Adapun indikator budaya sekolah yang terjadi pada SMP Negeri 1 Panei yaitu inisiatif individu, pengarahan, integrasi, dukungan manajemen, kontrol, identitas, sistem imbalam dan pola komunikasi.
Indikator inisiatif individu yaitu memiliki kebebasan dalam mengemukakan pendapat dan dapat mempertanggungjawabkan setiap pendapat yang dikemukakan, seperti dalam rapat guru berani mengemukakan pendapat. Pengarahan yaitu sejauh mana sekolah menciptakan dengan jelas sasaran dan harapan yang diinginkan. Kejelasan visi sekolah yang disampaikan pada setiap unsur di sekolah dapat membangkitkan kinerja guru.

Integrasi yaitu sejauh mana sekolah dapat mendorong unit-unit sekolah untuk bekerja dengan cara terkoordinasi. Dukungan manajemen yaitu sejauh mana kepala sekolah dapat memberikan komunikasi atau arahan, bantuan serta dukungan yang jelas terhadap guru maupun siswa-siswi. Kontrol yaitu sejumlah peraturan dan pengawasan langsung yang digunakan untuk mengawasi dan mengendalikan perilaku para warga sekolah. Identitas yaitu sejauh mana para warga sekolah dapat mengidentifikasi dirinya sebagai suatu kesatuan dalam lingkup sekolah. Sistem imbalan yaitu sejauh mana alokasi imbalan didasarkan prestasi kerja guru, bukan didasarkan senioritas, sikap pilih kasih dan sebagainya. Dan pola komunikasi yaitu sejauh mana kejelasan penyampaian informasi setiap unsur di sekolah.

Secara keseluruhan budaya sekolah diperoleh nilai rata-rata 3,70 dengan kriteria jawaban kuat. Untuk nilai tertinggi yaitu diperoleh nilai rata-rata 4,35 pada indikator sistem imbalan dengan kriteria sangat kuat pada kategori alokasi imbalan yang diberikan kepada guru atas prestasi kerjanya. Sedangkan untuk nilai terendah yaitu diperoleh nilai ratarata 3,13 yaitu dengan kriteria sedang pada hirarki formal komunikasi.

\section{3) Gambaran Kinerja Guru Pada SMP Negeri 1 Panei}

Kinerja guru dapat ditingkatkan apabila adanya kesesuaian antar pekerjaan dengan keahliannya, dan menempatkan guru sesuai dengan keahliannya. Apabila guru tersebut tidak ditempatkan sesuai dengan keahliannya, maka akan berdampak buruk terhadap anak didik yang diajarkannya.

Pengukuran kinerja guru pada SMP Negeri 1 Panei yaitu dengan Peraturan Menteri Pendidikan Nasional Nomor 16 tahun 2007 tentang standar kualifikasi akademik dan kompetensi guru. Pengukuran kinerja guru dengan menguasai karakteristik peserta didik yaitu mengidentifikasi karakteristik belajar peserta didik, para guru melakukannya dengan melakukan pendekatan dengan siswa baik saat proses pembelajaran berlangsung. Menguasai teori belajar dan prinsip pembelajaran yaitu guru menggunakan teknik pembelajaran yang dapat membuat siswa terdorong untuk belajar. Melakukan pengembangan kurikulum yaitu para 
guru menyesuaikan pembelajaran sesuai dengan kurikulum yang berlaku.

Selanjutnya kinerja guru pada dimensi kegiatan pembelajaran yang mendidik yaitu meningkatkan kreativitas peserta didik serta memotivasi peserta didik untuk belajar. Pengembangan potensi peserta didik yaitu melakukan interaksi terhadap peserta didik agar dapat mengidentifikasi potensi yang ada pada peserta didik tersebut. Pada komunikasi dengan peserta didik juga memberikan efek yang positif kepada peserta didik agar lebih berani aktif dalam proses pembelajaran.

Proses penilaian dan evaluasi yaitu melaksanakan kegiatan pembelajaran mulai dari penggunaan media dan sumber belajar siswa, serta penggunaan metode pembelajaran sehingga para guru mampu mengadakan evaluasi atau penilaian pembelajaran terhadap kemampuan yang dimiliki para siswa. Bertindak sesuai aturan atau norma seperti sesama warga sekolah dapat menerima perbedaan yang ada di sekitar sekolah tanpa adanya diskriminatif. Selanjutnya menunjukkan pribadi yang dewasa dan teladan yaitu setiap warga sekolah baik pimpinan, guru, staf maupun peserta didik dapat saling menghormati dan mau menerima masukan untuk kemajuan setiap individu yang ada di sekolah. Selanjutnya dalam dalam melaksanakan tugas para guru-guru memberikan kontribusi untuk pengembangan sekolah.

Pada komunikasi dengan sesama guru, peserta didik dan masyarakat yaitu menyampaikan informasi perkembangan pendidikan kepada peserta didik serta yang terakhir mengembangkan keprofesionalan melalui tindakan yang reflektif yaitu melakukan evaluasi diri secara berkelanjutan bagi para pendidik dan menggunakan manfaat dari teknologi untuk pengembangan tiap tenaga pendidik yang ada di sekolah.

Secara keseluruhan kinerja guru diperoleh nilai rata-rata 3,58 dengan kriteria jawaban baik. Untuk nilai tertinggi yaitu diperoleh nilai rata-rata 4,08 dengan kriteria jawaban baik pada sub indikator alokasi waktu dalam pelaksanaan pembelajaran. Sedangkan untuk nilai terendah yaitu diperoleh nilai ratarata 3,37 dengan kriteria cukup baik pada sub indikator kesesuaian penyusunan silabus dengan kurikulum, kategori kesesuaian urutan penyampaian materi, kategori tanggapan guru atas jawaban peserta didik, kategori penghargaan guru atas prinsip pancasila, kategori kepedulian guru kepada rekan kerja, dan kategori keaktifan guru diluar pembelajaran.

\section{b. Deskriptif Kuantitatif}

\section{1) Regresi Linear Berganda}

Penelitian ini memiliki tujuan untuk menganalisis pengaruh kepemimpinan kepala sekolah dan budaya sekolah terhadap kinerja guru. Analisis data dalam penelitian ini menggunakan analisis regresi linier berganda. Analisis regresi linier berganda digunakan untuk mengetahui pengaruh variabel bebas $(X)$ dan variabel terikat (Y), dimana $X$ adalah kepemimpinan kepala sekolah, budaya sekolah dan $Y$ adalah kinerja guru. Maka dilakukan perhitungan menggunakan program aplikasi SPSS versi 21 dengan hasil hitung regresi sebagai berikut:

Tabel 2

Hasil Regresi Linier Berganda Coefficients $^{a}$

\begin{tabular}{|c|c|c|c|c|}
\hline \multirow{2}{*}{\multicolumn{2}{|c|}{ Moscl }} & \multicolumn{2}{|c|}{ 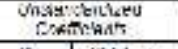 } & \multirow{2}{*}{ 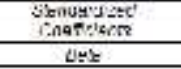 } \\
\hline & & ע & SE: LIICS & \\
\hline \multirow[t]{3}{*}{$T$} & Pannitent & 21216 & ग2०0 & \\
\hline & 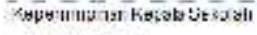 & $\bar{x} y \bar{j}$ & 286 & 362 \\
\hline & $=$ =UJufuSck:IJi & 1080 & 298 & $<0^{\circ}$ \\
\hline
\end{tabular}

a. Dependent Variabel: Kepuasan Konsumen Sumber: hasil pengolahan data dengan SPSS versi 21

Berdasarkan hasil pengolahan data pada tabel 2 di atas diperoleh model persamaan $\mathrm{Y}=$ $21,276+0,839 X_{1}+1,089 X_{2}$, artinya terdapat pengaruh yang positif antara kepemimpinan kepala sekolah $\left(\mathrm{X}_{1}\right)$ dan budaya sekolah $\left(\mathrm{X}_{2}\right)$ terhadap kinerja guru ( $\mathrm{Y}$ ) pada SMP Negeri 1 Panei.

\section{2) Korelasi dan Koefisien Determinasi}

Hasi korelasi dan koefisien determinasi dapat dilihat pada tabel berikut:

\section{Tabel 3}

Hasil Korelasi dan Koefisien Determinasi Mndal Cimmario

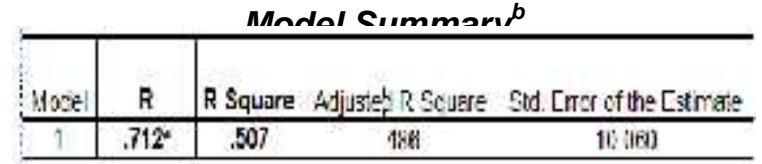

a. Predictors: (Constant), Kepemimpinan

Kepala Sekolah, Budaya Sekolah

b. Dependent Variabel: Kinerja Guru

Sumber: hasil pengolahan data dengan SPSS versi 21

Berdasarkan tabel 3 diperoleh nilai $r=$ diperoleh korelasi nilai $r$ sebesar 0,712 , artinya terdapat hubungan yang kuat dan positif antara variabel kepemimpinan kepala sekolah dan budaya sekolah dengan kinerja guru pada SMP Negeri 1 Panei sesuai dengan kriteria koefisien korelasi pada tabel 5. Kemudian diperoleh nilai koefisien determinasi yaitu 0,507 , artinya baik tidaknya kinerja guru dijelaskan sebesar $50,7 \%$ oleh kepemimpinan kepala sekolah dan budaya sekolah selebihnya $49,3 \%$ dijelaskan oleh faktor lain seperti lingkungan kerja, etos kerja dan motivasi kerja yang tidak dijelaskan dalam penelitian ini.

\section{3) Uji Hipotesis}

\section{a) Uji Simultan (Uji F)}

Pengujian ini dilakukan secara simultan, yaitu dilakukan untuk menentukan diterima atau 
ditolaknya hipotesis. Pengujian hipotesis dilakukan untuk mengetahui apakah variabel kepemimpinan kepala sekolah dan budaya sekolah yang diuji berpengaruh terhadap kinerja guru. Jika $F_{\text {hitung }}>F_{\text {tabel }}$ atau signifikansi $\leq 0,05$, maka $\mathrm{H}_{0}$ ditolak.

Untuk menghasilkan suatu kesimpulan yang valid, maka harus dilakukan uji hipotesis dengan menggunakan program SPSS versi 21 .

Tabel 4

Hasil Uji Simultan (Uji F)

ANOVA $^{a}$

\begin{tabular}{|c|c|c|c|c|c|c|}
\hline \multicolumn{2}{|l|}{ Mrocai } & 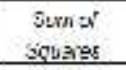 & $\underline{L} \mathbf{r}$ & $\begin{array}{l}\text { Musw } \\
\text { Souare }\end{array}$ & $\mathrm{F}$ & Sig. \\
\hline 1 & [exyession & -4002.000 & -2 & $\underline{2} 3+\underline{2}, 0$ & 23.183 & $000^{\circ}$ \\
\hline & Isecidiyt & $4 n 338$ & 45 & $19+196$ & & \\
\hline
\end{tabular}

a. Dependent Variabel:Kinerja Guru

b. Predictors: (Constant), Kepemimpinan Kepala Sekolah, Budaya Sekolah

Sumber: hasil pengolahan data dengan SPSS versi 21

Berdasarkan tabel 4 di atas, diperoleh

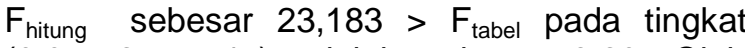
$(0,05 ; 2$ vs 45$)$ adalah sebesar 3,20 . Oleh karena $F_{\text {hitung }}>F_{\text {tabel }}$ atau taraf signifikansi 0,000 $<$ dari alpha 0,05, maka Ho ditolak, artinya kepemimpinan kepala sekolah dan budaya sekolah berpengaruh positif dan signifikan terhadap kinerja guru pada SMP Negeri 1 Panei secara simultan.

\section{b) Uji Parsial (Uji t)}

Pengujian ini dilakukan secara parsial yang dilakukan untuk menentukan diterima atau ditolaknya hipotesis. Pengujian hipotesis dilakukan untuk mengetahui apakah variabel kepemimpinan kepala sekolah dan budaya sekolah yang diuji berpengaruh terhadap kinerja guru. Jika $t_{\text {hitung }}>t_{\text {tabel }}$ atau signifikansi $\leq 0,05$, maka $\mathrm{H}_{0}$ ditolak.

Tabel 5

Hasil Uji Parsial (Uji t)

Coefficients ${ }^{a}$

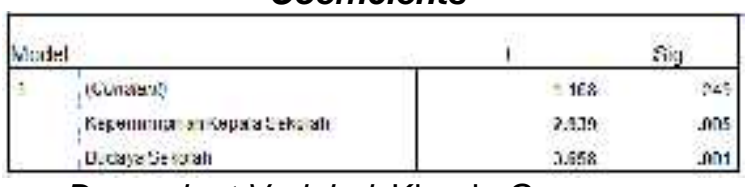

a. Dependent Variabel: Kinerja Guru

Sumber: hasil pengolahan data dengan SPSS versi 21

Berdasarkan tabel 5 diperoleh nilai $t_{\text {hitung }}$ pada variabel kepemimpinan kepala sekolah didapat $t_{\text {hitung }}$ sebesar 2,939 $>t_{\text {tabel }}$ dengan ketentuan n-k-1 pada level kesalahan $5 \%$ atau $0,05 \quad(48-2-1=45)$ sebesar 2,014 atau taraf siginifikan 0,005 < dari alpha 0,05 maka $\mathrm{Ho}$ ditolak, artinya kepemimpinan kepala sekolah berpengaruh positif dan signifikan terhadap kinerja guru pada SMP Negeri 1 Panei.Sementara hasil tabel 5 di atas pada variabel budaya sekolah didapat $t_{\text {hitung }} 3.658>$ $t_{\text {tabel }}$ sebesar 2,014 atau taraf signifikan 0,001< dari alpha 0,05 maka Ho ditolak, artinya budaya sekolah berpengaruh positif dan signifikan terhadap kinerja guru pada SMP Negeri 1 Panei.

\section{Evaluasi}

\section{a. Kepemimpinan Kepala Sekolah pada SMP} Negeri 1 Panei

Dimensi kepribadian, pada indikator keinginan kepala sekolah untuk pengembangan diri sebesar 3,15 dengan kriteria jawaban cukup baik, untuk mengatasinya sebaiknya kepala sekolah lebih memperhatikan untuk pengembangan diri kepala sekolah agar dapat memimpin sekolah dengan lebih baik dengan mengikuti pelatihan-pelatihan untuk kepala sekolah serta menerima saran dari sesama rekan kerja untuk kepentingan bersama di sekolah tersebut.

Untuk dimensi manajerial dengan indikator memberdayakan sumber daya sekolah diperoleh nilai rata-rata 3,46 dengan kriteria nilai jawaban baik, untuk meningkatkannya sebaiknya kepala sekolah lebih giat merencanakan program untuk memberdayakan setiap potensi yang ada di sekolah untuk kepentingan bersama. Indikator memanfaatkan teknologi informasi diperoleh nilai rata-rata 3,29 dengan kriteria nilai jawaban cukup baik, untuk mengatasinya sebaiknya kepala sekolah merekrut guru atau staf yang ahli dibidangnya agar dapat memanfaatkan teknologi yang ada pada sekolah tersebut.

$$
\text { Selanjutnya untuk dimensi }
$$
kewirausahaan dengan indikator motivasi kepala sekolah untuk mencapai keberhasilan sekolah diperoleh nilai rata-rata 3,77 dengan kriteria nilai jawaban baik, untuk meningkatkannya adalah pimpinan harus berusaha memberikan ide-ide untuk memajukan sekolah sehingga para guru lebih aktif memberikan tanggapan atas ide kepala sekolah tersebut.

Pada dimensi supervisi dengan indikator merencanakan program supervisi akademik dalam meningkatkan keprofesionalisme guru diperoleh nilai rata-rata 3,65 dengan kriteria nilai jawaban baik, untuk mengatasi hal ini kepala sekolah sebaiknya lebih memperhatikan program-program perencanaan untuk mengembangkan kemampuan guru-guru tersebut dan memberikan perhatian terhadap pengembangan kualitas kerja para guru. Indikator menindak lanjuti hasil program supervisi akademik diperoleh nilai 3,67 dengan kriteria nilai jawaban baik, untuk mengatasi hal ini sebaiknya kepala sekolah lebih serius menanggapi program-program supervisi akademik seperti melakukan pelatihan kepada guru-guru.

Selanjutnya pada dimensi sosial dengan indikator kemampuan kepala sekolah berpartisipasi dalam kegiatan sosial 
kemasyarakatan diperoleh nilai 3,77 dengan kriteria nilai jawaban baik, untuk mengatasi hal ini sebaiknya kepala sekolah lebih memberikan perhatian terhadap kegiatan-kegiatan sekolah terutama yang berhubungan dengan lingkungan sekitar ataupun masyarakat luar agar citra sekolah maupun nama sekolah baik di mata masyarakat.

\section{b. Budaya Sekolah pada SMP Negeri 1 Panei}

Indikator inisiatif individu yaitu kategori kebebasan guru dalam penyampaian pendapat dengan nilai 3,21 dengan kriteria jawaban sedang, untuk meningkatkannya sebaiknya guru-guru lebih berani untuk mengemukakan pendapat baik masukan atau kritikan untuk membangun manajemen sekolah yang lebih baik. Pada indikator pengarahan yaitu kategori kejelasan visi sekolah yang disampaikan dengan nilai 3,54 dengan kriteria jawaban kuat, untuk meningkatkannya sebaiknya setiap warga sekolah bisa atau mampu untuk menjelaskan visi sekolah kepada setiap unsur yang ada disekolah. Pada indikator integrasi yaitu kategori kemampuan guru bekerja terkoordinasi dengan nilai 3,67 dengan kriteria jawaban kuat, untuk mengatasinya para guru sebaiknya lebih ekstra dalam bekerja baik secara terkoordinasi maupun tidak dengan sesama rekan kerjanya.

Pada indikator kontrol yaitu kategori pengawasan yang dilakukan sekolah dengan nilai 3,65 dengan kriteria jawaban kuat, untuk mengatasinya setiap warga sekolah sebaiknya lebih mengawasi kegiatan-kegiatan yang terjadi baik itu pimpinan maupun bawahan. Pada indikator identitas yaitu kategori kesadaran guru sebagai satu kesatuan unsur dalam sekolah dengan nilai 3,17 dengan kriteria jawaban sedang, untuk mengatasinya para guru sebaiknya meningkatkan kesadaran bahwa mereka adalah bagian dari sekolah untuk meningkatkan pendidikan bagi siswa-siswanya. Selanjutnya pada indikator pola komunikasi yaitu kategori hirarki formal yang membatasi komunikasi di sekolah diperoleh nilai rata-rata 3,13 dengan kriteria jawaban sedang, maka untuk mengatasinya setiap unsur yang di sekolah sebaiknya lebih memperhatikan komunikasi yang ada di sekolah.

\section{c. Kinerja Guru pada SMP Negeri 1 Panei}

Indikator mengidentifikasi karakteristik peserta didik dengan nilai 3,54 dengan kriteria jawaban baik, untuk mengatasinya para guru sebaiknya lebih mengetahui karakteristik tiap peserta didik agar dalam menyampaikan materi dapat diterima peserta didik dengan baik. Indikator kesempatan peserta didik untuk berpartisipasi dengan nilai 3,54 dengan kriteria jawaban baik, untuk mengatasinya para guru lebih memotivasi para peserta didik untuk lebih aktif di dalam kelas maupun di luar kelas. Sedangkan indikator membantu pengembangan potensi dengan nilai 3,39 dengan kriteria jawaban cukup baik, untuk mengatasinya para guru juga sebaiknya lebih ekstra untuk mendorong peserta didik untuk mengembangkan potensi yang ada pada peserta didik.

Indikator kesempatan peserta didik dalam penguasaan materi dengan nilai 3,39 dengan kriteria jawaban cukup baik, untuk mengatasinya para guru sebaiknya lebih memberikan kesempatan kepada peserta didik agar lebih mampu dan mandiri dalam menerima pelajaran yang diberikan ataupun materi yang disampaikan. Indikator kesesuaian penyusunan silabus dengan kurikulum dengan nilai 3,37 dengan kriteria jawaban cukup baik, untuk mengatasinya para guru sebaiknya menyesuaikan silabus dengan kurikulum yang berlaku dan menyesuaikan dengan materi yang akan diajarkan.

Indikator penyusunan rencana pembelajaran dengan silabus dengan nilai 3,50 dengan kriteria jawaban baik, untuk mengatasinya para guru sebaiknya menyesuaikan pembelajaran sesuai dengan silabus agar pembelajaran dapat berjalan dengan baik. Indikator urutan penyampaian materi pembelajaran dengan yang direncanakan diperoleh nilai 3,37 dengan kriteria jawaban cukup baik, untuk mengatasinya para guru sebaiknya terlebih dahulu memperlajari materi yang akan disampaikan kepada peserta didik agar dalam penyampaian tidak merugikan peserta didik tersebut.

Indikator peningkatan daya kreativitas peserta didik dengan nilai 3,50 dengan kriteria jawaban baik, untuk meningkatkannya sebaiknya para guru mengajari peserta didik dengan cara yang menyenangkan agar daya kreativitas peserta didik dapat meningkat dengan sendirinya. Indikator penggunaan alat bantu dalam memotivasi peserta didik dengan nilai 3,50 dengan kriteria jawaban baik, untuk meningkatkannya sebaiknya guru para aktif menggunakan alat bantu seperti teknologi dalam mengajar agar lebih memotivasi peserta didik. Indikator tanggapan terhadap pertanyaan yang diberikan dengan nilai 3,50 untuk mengatasinya guru sebaiknya lebih aktif memberikan pertanyaan agar peserta didik tersebut lebih berani memberikan tanggapan pada saat pembelajaran.

Indikator tanggapan guru atas pertanyaan dengan nilai 3,37 dengan kriteria jawaban cukup baik, untuk mengatasinya para guru sebaiknya memberikan tanggapan yang mudah dipahami oleh peserta didik. Indikator perhatian guru atas jawaban peserta didik dengan nilai 3,39 dengan kriteria jawaban cukup baik, untuk mengatasinya para guru harus lebih tanggap merespon atas pertanyaan peserta didik. Indikator kesesuaian alat 
penilaian pembelajaran dengan nilai 3,39 dengan kriteria jawaban cukup baik, untuk mengatasinya para guru sebaiknya lebih memahami alat dalam penilaian pembelajaran agar pembelajaran dapat berjalan dengan lancar.

Indikator penghargaan guru atas prinsip pancasila sebagai ideologi dasar negara dengan nilai 3,37 dengan kriteria jawaban cukup baik, untuk mengatasinya para guru sebaiknya lebih memahami prinsip yang dimaksud dan dapat menerapkan prinsip tersebut. Indikator rasa saling menghormati perbedaan dengan nilai 3,50 dengan kriteria jawaban baik, untuk meningkatkannya sebaiknya para guru lebih meningkat rasa saling menghormati perbedaan antar sesama rekan kerja. Indikator rasa persatuan kesatuan diantara rekan kerja dengan nilai 3,54 dengan kriteria jawaban baik, untuk meningkatkannya sebaiknya sesama rekan kerja mau saling membantu dalam meningkatkan kualitas kinerja maupun untuk kemajuan sekolah.

Indikator kesopanan guru dalam berperilaku dengan nilai 3,50 dengan kriteria jawaban baik, untuk meningkatkannya sebaiknya para guru harus semakin meningkatkan kesopanan berperilaku di dalam lingkup sekolah maupun di luar sekolah. Indikator kedewasaan guru menerima masukann dengan nilai 3,50 dengan kriteria jawaban baik, untuk meningkatkannya sebaiknya para guru lebih lapang menerima setiap masukan agar kinerja guru dapat semakin baik. Indikator rasa keadilan yang diberikan kepada peserta didik dengan nilai 3,50 dengan kriteria jawaban baik, untuk meningkatkannya sebaiknya para guru harus memberikan penilaian yang merata terhadap peserta didik sesuai dengan prestasi peserta didik agar tidak menimbulkan perbedaan antara peserta didik tersebut.

Indikator kepedulian guru kepada rekan kerja dengan nilai 3,37 dengan kriteria jawaban cukup baik, untuk mengatasinya para guru sebaiknya membuang rasa egoisme dalam diri para guru agar kepedulian antar sesama rekan kerja tetap terjalin dengan baik. Indikator menyampaikan informasi perkembangan pendidikan peserta didik dengan nilai 3,52 dengan kriteria jawaban baik, untuk meningkatkannya sebaiknya para guru lebih aktif dalam menyampaikan perkembangan peserta didik kepada orang tua peserta didik.

$$
\text { Indikator keaktifan guru diluar }
$$
pembelajaran dengan nilai 3,37 dengan kriteria jawaban cukup baik, untuk mengatasinya para guru sebaiknya lebih memberikan diri untuk kegiatan diluar pembelajaran. Indikator komunikasi guru dengan masyarakat luar dengan nilai 3,50 dengan kriteria jawaban baik, untuk meningkatkannya sebaiknya para guru lebih menjaga hubungan dan menjalin kerjasama yang baik dengan masyarakat.

\section{KESIMPULAN DAN SARAN}

1. Kesimpulan

a. Hasil analisis deskriptif kualitatif kepemimpinan kepala sekolah pada SMP Negeri 1 Panei berada pada rata-rata jawaban keseluruhan 3,81 dengan kriteria baik. Nilai rata-rata tertinggi sebesar 4,35 dengan kriteria sangat tinggi berada pada dimensi manajerial dengan indikator mengelola sumber daya pendukung (sarana dan prasarana). Sedangkan nilai terendah dengan nilai rata-rata sebesar 3,15 dengan kriteria cukup baik pada dimensi kepribadian dengan indikator keinginan kepala sekolah untuk pengembangan diri.

b. Hasil analisis deskriptif kualitatif budaya sekolah pada SMP Negeri 1 Panei berada pada rata-rata jawaban keseluruhan 3,70 dengan kriteria kuat. Nilai rata-rata tertinggi sebesar 4,35 dengan kriteria nilai sangat kuat berada pada indikator sistem imbalan dengan kategori alokasi imbalan yang diberikan kepada guru atas prestasi kerjanya. Sedangkan untuk nilai terendah yaitu 3,13 dengan kriteria jawaban sedang berada pada indikator pola komunikasi dengan kategori hirarki formal membatasi komunikasi yang terjadi di sekolah.

c. Hasil analisis deskriptif kualitatif kinerja guru pada SMP Negeri 1 Panei berada pada nilai rata-rata jawaban keseluruhan 3,58 dengan kriteria jawaban baik. Nilai rata-rata tertinggi sebesar 4,08 dengan kriteria jawaban baik berada pada indikator alokasi waktu dalam pelaksanaan pembelajaran. Sedangkan nilai terendah dengan nilai rata-rata sebesar 3,37 dengan kriteria jawaban cukup baik pada indikator kesesuaian penyusunan silabus dengan kurikulum, indikator kesesuaian urutan penyampaian materi, indikator tanggapan guru atas jawaban peserta didik, indikator penghargaan guru atas prinsip pancasila, indikator kepedulian guru kepada rekan kerja, dan indikator keaktifan guru diluar pembelajaran.

d. Hasil analisis regresi $\hat{Y}=21,276+0,839 X_{1}+$ $1,089 \mathrm{X}_{2}$, artinya terdapat pengaruh yang positif antara kepemimpinan kepala sekolah $\left(X_{1}\right)$ dan budaya sekolah $\left(X_{2}\right)$ terhadap kinerja guru $(Y)$ pada SMP Negeri 1 Panei.

e. Hasil nilai korelasi menunjukkan bahwa terdapat hubungan kuat dan positif yaitu sebesar 0,712 antara variabel kepempinan kepala sekolah dan budaya sekolah dengan kinerja guru pada SMP Negeri 1 Panei sesuai dengan kriteria koefisien korelasi pada tabel 5. Kemudian diperoleh nilai koefisien determinasi yaitu 0,507, artinya baik tidaknya kinerja guru dijelaskan sebesar $50,7 \%$ oleh kepemimpinan kepala sekolah 
dan budaya sekolah selebihnya 49,3\% dijelaskan oleh faktor lain seperti lingkungan kerja, etos kerja dan motivasi kerja yang tidak dijelaskan dalam penelitian ini.

f. Hasil pengujian $F_{\text {hitung }}$ sebesar 23,183 > $F_{\text {tabel }}$ pada tingkat $(0,05,2$ vs 45$)$ adalah sebesar 3,20. Oleh karena $F_{\text {hitung }}>F_{\text {tabel }}$ atau taraf signifikansi $0,000<$ dari alpha 0,05 maka Ho ditolak, artinya kepemimpinan kepala sekolah dan budaya sekolah berpengaruh positif dan signifikan terhadap kinerja guru pada SMP Negeri 1 Panei.

g. Hasil pengujian didapat variabel kepemimpinan kepala sekolah didapat $t_{\text {hitung }}$ sebesar 2,939 $>t_{t a b e l}$ sebesar 2,012 atau taraf siginifikan 0,005 < dari alpha 0,05 maka Ho ditolak, artinya kepemimpinan kepala sekolah berpengaruh positif dan signifikan terhadap kinerja guru pada SMP Negeri 1 Panei dan variabel budaya sekolah didapat $t_{\text {hitung }} 3,658>t_{\text {tabel }}$ sebesar 2,012 atau taraf signifikan 0,001 < dari alpha 0,05 maka $\mathrm{H}_{0}$ ditolak, artinya budaya sekolah berpengaruh positif dan signifikan terhadap kinerja guru pada SMP Negeri 1 Panei.

\section{Saran}

a. Kepemimpinan kepala sekolah pada SMP Negeri 1 Panei masih perlu ditingkatkan, untuk itu sebaiknya pimpinan sekolah memberikan perhatian untuk pengembangan diri maupun sekolah tersebut, menggunakan dan memanfaatkan fasilitas yang telah disediakan oleh instansi, memberikan pelatihan secara rutin untuk menggali potensi para guru serta meningkatkan kepedulian terhadap lingkungan.

b. Budaya sekolah pada SMP Negeri 1 Panei masih perlu ditingkatkan karena masih ada indikator yang belum optimal. Untuk itu instansi sebaiknya para guru lebih berani mengemukakan pendapat untuk kemajuan sekolah serta seluruh unsur yang ada disekolah lebih membiasakan diri untuk berkomunikasi dengan sesama warga sekolah agar terciptanya semangat kerja diantara sesama warga sekolah dan dapat memajukan sekolah.

c. Kinerja guru SMP Negeri 1 Panei masih perlu ditingkatkan karena masih ada indikator yang belum optimal. Untuk mengoptimalkan kinerja guru, maka instansi sebaiknya memberikan perhatian khusus kepada setiap guru agar para guru dapat menyelesaikan tugas dengan baik dan kepala sekolah harus berusaha menjalin hubungan yang dekat dengan para guru serta memberikan pembinaan secara formal dengan memotivasi para guru agar dapat bekerja dengan lebih baik.

\section{E. DAFTAR PUSTAKA}

Bangun, Wilson. 2012. Manajemen Sumber Daya Manusia. Jakarta: Erlangga

Mathis, Robert. L, John H. Jackson. 2011. Human Resources Management. Edisi Kesepuluh. Terjemahan Diana Angelica, Jakarta: Salemba Empat.

Mondy, Wayne. 2008. Manajemen Sumber Daya Manusia. Jakarta: Erlangga.

Mutohar, Masrokan P. 2013. Manajemen Mutu Sekolah. Yogyakarta: Ar-Ruzz Media.

Peraturan Menteri Pendidikan Nasional Nomor 13 Tahun 2007 Tentang Standar Kualifikasi Akademik dan Kompetensi Guru.

Peraturan Menteri Pendidikan Nasional Nomor 16 Tahun 2007 Tentang Standar Kualifikasi Akademik dan Kompetensi Guru

Rahman, dkk. 2006. Peran Strategis Kepala Sekolah Dalam Meningkatkan Mutu Pendidikan. Jatinangor: Alqaprint.

Rivai, Viethzal. 2005. Performance Appraisal. Jakarta: PT. Raja Grasindo Persada.

Robbins, Stephen P. 2002. Perilaku Organisasi. Edisi Kelima. Jakarta: Erlangga.

Supardi. 2016. Kinerja Guru. Jakarta: RajaGrafindo Persada.

Susanto, Pendi. 2016. Produktivitas Sekolah. Bandung: Alfabeta.

Sutrisno, H Edy. 2009. Manajemen Sumber Daya Manusia. Jakarta: Kencana.

Wahjosumidjo, 2002, Kepemimpinan Kepala Sekolah, Jakarta: Raja Grafindo Persada.

Wirawan. 2014. Kepemimpinan. Jakarta: RajaGrafindo Persada. 